\title{
A Comparative Study of Negation in Igbo and Etulo
}

\author{
Chikelu Ihunanya Ezenwafor-Afuecheta \\ Department of Linguistics, Nnamdi Azikiwe University, Awka, Nigeria
}

\section{Email address:}

ci.ezenwafor@unizik.edu.ng

\section{To cite this article:}

Chikelu Ihunanya Ezenwafor-Afuecheta. A Comparative Study of Negation in Igbo and Etulo. International Journal of Applied Linguistics and Translation s. Vol. 7, No. 3, 2021, pp. 83-86. doi: 10.11648/j.ijalt.20210703.11

Received: January 13, 2021; Accepted: May 19, 2021; Published: August 23, 2021

\begin{abstract}
This paper examines the negation typology of two Benue Congo languages, Igbo and Etulo. It discusses the similarities and differences evident in the negation marking strategies of both languages. From our findings, it is observed that despite the differences, Etulo and Igbo unanimously make a distinction between the standard negation marker and other types of negation markers such as the prohibitive negation marker as in Igbo and the interrogative negation marker as in Etulo. The distinction made in both languages lends support to the assumption in negation studies that the negative morpheme associated with standard negation often differs from the negative marker used in the negation of other construction types such as the prohibitive, and polar questions. This work adopts a descriptive approach in the analysis of the Igbo and Etulo language data. The Igbo language data presented and analyzed were obtained from the existing grammatical description of negation in Igbo while the Etulo language data were obtained from Etulo language consultants using the elicitation method.
\end{abstract}

Keywords: Etulo, Igbo, Negation, Prohibitive, Polar Questions, Standard Negation

\section{Introduction}

Negation is considered a universal category of the human language. Although all human languages are characterized by the feature of negation, a great deal of variation exists in the negation marking strategies that languages adopt, the number of negation morphemes, as well as the distributional pattern of the negation markers. Every language develops its own set of negative elements and rules for using them.

This paper gives a comparative linguistic description of negation in two related languages of the Benue Congo sub group. These languages (Igbo and Etulo) are spoken in Nigeria. Igbo is one of the three major languages of Nigeria. It is spoken by about 20 million speakers in the South Eastern part of Nigeria. The Etulo language has fewer speakers. It is spoken in Benue and Taraba states in the North Eastern part of Nigeria. Both languages are tonal and have a Predominant SVO word order.

Studies on the typology of negation in Benue Congo languages indicate that a large number of these languages employ the use of varied negative morphemes associated with specific construction types cf: Ejele [1], Ndimele [2], Obiamalu [3], Bond [4], Akinlabi [5]. This reaffirms the view held in Miestamo [6] that the negative morpheme used in a language may vary depending on the construction type. This paper focuses on the negation of different construction types such as the simple declarative, the imperative or prohibitive and the interrogative (polar questions).

The Igbo language data presented and analysed were obtained from the existing grammatical description of negation in Igbo (see Ndimele [2], Obiamalu [3]. The Etulo language data were obtained from Etulo language informants using a structured questionnaire. The Etulo language data is represented using the IPA symbols.

Negation is defined as a process or construction in grammatical and semantic analysis which typically expresses the contradiction of some or all of a sentence's meaning Crystal [7]. Similarly, Givon [8] states that while affirmatives are used to convey new information on the presumption of ignorance of the hearer, negatives are used to correct misguided beliefs on the assumption of the hearer's error. Negation has been classified in various ways in the existing literature. Karen [9] distinguishes between sentence and constituent negation. Dahl [10] makes a distinction between morphological and syntactic negation. According to Dahl, morphological negation involves such morphological processes as affixation and reduplication while syntactic negation involves the use of negative particles and auxiliaries. A distinction is also made between standard negation and 
other forms of negation in a language. The term 'standard negation' originates from Payne [11]. It is described as the form of negation associated with the most minimal or basic sentence in a language. Miestamo [6] characterizes standard negation as the basic means that languages employ in the negation of verbal declarative main clauses. It is therefore possible that some grammatical constructions in a language may be negated with a negation marker different from the one used in standard negation. Kahrel [12] also observes from a 40 language sample that there are some negative constructions in languages that have negative markers different from that used in standard negation. Such construction types mostly include the imperatives, existentials, and non verbal clauses. In contrast with standard negation in Iquitto, a moribund Zaponoan language, Hansen [13] describes a non standard negation strategy in finite subordinate clauses. Similarly, Tararova [14] makes a distinction between standard negation and negative doubling in Chipileno Spanish. The variance in the use of negative morphemes is found in many languages of the world. Many languages of the Benue Congo subgroup of Niger-Congo such as Igbo, Etulo, Ewe and Esan distinguish between standard and non standard negative markers.

\section{Negation in Igbo}

The negation of basic declarative clauses (standard negation) is marked by the negative suffix -ghi/ghị. As with most Igbo affixes, the vowel of the negative suffix changes in adherence to the rule of vowel harmony resulting in the two forms stated above. The negative inflectional suffix attaches to the verb root. It may also attach to the auxiliary in habitual and anticipative constructions. Consider the following examples:

1a) Ọ́ zà-rà ụ́lọ 3SG sweep-PST house

'She swept the house'

1b) Ọ̀ zá-ghị ụ́lọ 3SG cook-NEG food

'She did not cook food'

2a) Ézè gbù-rù éwú PN kill-PST goat 'Eze killed a goat'

2b) Ézè é-gbu -ghị éwú PN AGR-kill-NEG goat 'Eze did not kill a goat'

In the above examples, the lexical verbs take the negative suffix. In (1b), the negative suffix takes the form $g h i$ in adherence to the rule of vowel harmony while in $2 b$, it is realised as $g h i$ for this same reason. The standard negative marker ghi/ghi has no inherent tone. The tone that it bears in constructions is conditioned by the inherent tone of the verb root as in (1b) and (2b). In other words, the negative suffix is assigned a low tone if it attaches to an inherently low tone verb. It also bears a down stepped high if it attaches to an inherently high tone verb.

The use of auxiliaries is relevant in Igbo negation especially with the anticipative and habitual constructions. Below are some examples:

3a) Há gà èjé úkà 3PL AUX/FUT go church

'They will go to church'

3b) Há á-ga -ghị éjé úkà

3PL AGR-AUX-NEG go church

'They will not go to church'
4a) Àdá nà àkúzí ńkúzí
PN AUX/HAB teach teaching
'Ada is a teacher'
4b) Àdá á-na -ghị àkúzí ńkúzí
PN AGR-AUX/HAB-NEG teach teaching
'Ada is not a teacher'

In (3b) the negative suffix attaches to the anticipative auxiliary $g a$ while in $(4 \mathrm{~b})$, it attaches to the auxiliary $n a$. The tone of the negative marker in anticipative and habitual constructions is usually a downstep.

The negation of the Igbo perfective construction involves a slightly modified form of the standard negative marker is observed. Ndimele [2] analyzes the perfective negative marker beghi as being bimorphemic. The first morpheme be expresses perfectivity while the second morpheme ghi marks negation. The following examples are illustrative:
5a) Ó si -e -la ńri
3SG cook-OVS-PERF food
'He has cooked food'

\section{5b) Ò sí-bè-ghì ńrí \\ 3SG cook-PERF-NEG food \\ 'He has not cooked food'}

We stated in $\S 1$ that in some languages, the negative morpheme used in marking standard negation may differ from the negative marker used in other construction types such as the prohibitives and existentials. The variance in the use of negative morphemes is evident in Igbo. The imperative negative, also known as the prohibitive is marked by the negative suffix -la. This negative suffix attaches only to lexical verb roots. It differs from the standard negative marker ghi not only in form, but also in scope and distribution. The tone of the imperative negative marker is conditioned by the inherent tone of the verb root it attaches to1. If the verb root has an inherent high tone, the -la suffix is assigned a down stepped high. If the verb root bears an inherent low tone, the -la suffix is assigned a low tone. In (6b), the verb root $r i$ 'eat' is a high tone verb and so the imperative negative suffix bears a downstep tone. In (7b), the

\footnotetext{
1 The term 'inherent tone' is used here to refer to the tone of an individual lexical word before it enters a grammatical construction. It is often the case in tone languages that the inherent tones of lexical words may change when they enter into different grammatical constructions. It is important to note that it is the inherent tone of the lexical verb root ( not its grammatical tone) that conditions the tone of both the standard negative marker $-g h i / g h i$ and the imperative negative marker -la
} 
verb root $z \grave{a}$ 'sweep' is a low tone verb and therefore conditions the imperative negative suffix to bear a low tone. Below are some examples:
6a) Chíómá rì-é ńri PN eat-OVS food'
'Chioma eat!'
6b) Chíómá éri -la ńrí PN eat-PROH food'

'Chioma don't eat!'
7a) Èméká zà-á ụ́lọ PN sweep-OVS house 'Emeka sweep the house'

7b) Èméká ázà-là ụ́lọ̀ PN sweep-PROH house 'Emeka don't sweep the house'

\section{Negation in Etulo}

Etulo adopts the use of more than one negative morpheme in the marking of negation in different construction types. The standard negative marker in Etulo is the high tone negative particle bá cf: Ezenwafor [15]. It used in the negation of simple declarative constructions, the perfective, future and imperative constructions. The following examples are illustrative:
8a) àdì nw ' ǹd
PN kill goat
'Adi killed a goat'
8b) àdì nw ' ǹd ' bá
PN kill goat NEG
'Adi did not kill a goat'
9a) ó $1^{\prime}$ àfè wà
3SG write book PERF
'She has written a book'
9b) ó 1' àfè wà bá
3SG write book PERF NEG
'She has not written a book'
10a) gié ángw
eat yam
'Eat yam!'
10b) ká gié ángw ' bá
IMP eat yam NEG
'Eat yam!'
11a) àdì kà nw ' nd
PN FUT kill goat
'Adi will kill a goat'
11b) àdì kà nw ' nd ' bá
PN FUT kill goat NEG
'Adi will not kill a goat'

Examples (8) - (11) show that the negative particle bá consistently occurs at the sentence final position of different construction types. The Etulo prohibitive requires two morphemes: the high tone pre-verbal morpheme $k a$ and the post-verbal negative particle $b a ́$.

The negation of polar questions in Etulo involves a negative morpheme different from the standard negative marker. In other words, Etulo employs the use of more than one negative morpheme in the marking of negation. Consider the following examples:

12a) àdì gié ángw PN eat yam-Q

"Did Adi eat yam?"

12b) àdì gíé ángw' lóò PN eat yam NEG-Q

"Didn't Adi eat yam?"

13a) àdì kà yágbá ná únáà PN FUT be able sleep sleep-Q 'Can Adi sleep?'

13b) àdì kà yágbá ná úná loo PN FUT be able sleep sleep NEG-Q 'Can't Adi sleep?'

Etulo polar questions are characterized by vowel lengthening and a low tone. The last vowel of the word in the sentence final position is lengthened. The extra vowel which results from the vowel lengthening is assigned a low tone. The negated variants of polar questions involve the use of the dedicated negative marker ló which presumably bears an inherent high tone. The vowel of the negative particle is however lengthened resulting in the form lóo. It occurs in the sentence final position.

\section{A Comparison of Igbo-Etulo Negation Systems}

Although Igbo and Etulo are grouped as genetically related languages, a remarkable difference is observed in their negation typology. From the analysis of the of the available language data, the following observations are made:

The Igbo language tends toward morphological negation via the use of negative suffixes while Etulo tends toward syntactic negation via the use of negative particles.

The negation system of both languages lend support to the view of Payne [11] and Miestamo [6] that some language employ more than one negative morpheme in the marking of standard negation and the negation of other construction types. Igbo and Etulo fall in the group of languages that utilize more than one negative morpheme in the negation of different construction types. However, there exist some differences in the distribution and scope of the negative markers in both languages. In Igbo, the non-standard negative suffix is applicable to the prohibitive while in Etulo, the non-standard negative particle is applicable to polar questions.

\section{Conclusion}

This paper has attempted a comparative study of negation 
in two Benue Congo languages, Igbo and Etulo. The result of our findings reveals some differences and similarities in the negation systems of both languages. Using the data drawn from both languages, this paper agrees with the view of Payne [11] and Miestamo [6] that the negative morpheme associated with standard negation often differs from the negative markers used in the negation of construction types such as the prohibitive in Igbo and the interrogative (polar questions) in Etulo.

\section{References}

[1] Armstrong, G. (1989) Idomoid. In (John Bendor Samuel and Rhonda Hartell, Eds,). The Niger Congo languages. Lanham. Newyork: London.

[2] Bond, O. (2006). Negative strategies in Eleme. A seminar paper presented at the endangered languages academic programme, SOAS.

[3] Crystal, M. (2003) A dictionary of linguistics and phonetics (5th edition). Oxford: Blackwells.

[4] Ezenwafor C. I (2017) Negation Marking Strategies in Etulo. IOSR Journal Of Humanities And Social Science (IOSR-JHSS) Volume 22, Issue 10.

[5] Ezenwafor C. I. (2011) Negation in Etulo. MA Thesis: Nnamdi Azikiwe University, Awka.

[6] Dahl, O. (1979) Typology of sentence negation. Linguistics 17: 76-106.
[7] Ejele, P. (1995) The semantics of negation. In(E, Emenanjo and $\mathrm{O}$, Ndimele eds) Issues in African languages and linguistics: Essays in honour of Kay Williamson. NINLAN: Aba. 258-264.

[8] Hansen C. (2018) Subordinate and interrogative clause negation in Iquitto. In (Maria Koptsjevskaja-Tamm ed) Linguistic typology. De Gruyter Mouton. Vol. 22 (1) pp 119163.

[9] Hewson, J. Yoruba (West Benue Congo). (2006). Retrieved from the internet on 1st March, 2011.

[10] Kahrel, P. (1996) Aspects of Negation. PHD Thesis: University of Amsterdam.

[11] Karen C. (2020) Types of Negation. In (Viviane Déprez and M. Teresa Espinal eds.) Oxford Handbook on Negation. Oxford University Press.

[12] Miestamo, M. (2007). Negation: An overview of typological research. Language and Linguistics Compass 552-570.

[13] Ndimele, O. (2006). Negation marking in Igbo. In (O, Ndimele ed) Language and culture in Nigeria: A Festchrift for Okon Essien. NINLAN: Aba.

[14] Payne, J. (1985) Negation. In (Shopen, T. Ed.) Language typology and syntactic description. Cambridge: Cambridge University Press. Vol. 1. 197- 242.

[15] Tararova O. (2020) Pragmatic uses of negation in Chipileno Spanish (Mexico) Languages. https://doi.org.10.3390/languages5030028 